\title{
BUZZING TOO FAR? THE IDEOLOGICAL ECHO OF GLOBAL GOVERNANCE CONCEPTS ON THE LOCAL LEVEL: THE CASE OF THE MAFUNGAUTSI FOREST IN ZIMBABWE
}

\begin{abstract}
This article critically examines the effects of global development paradigms on the local level. Familiar examples of these 'buzzwords', are 'empowerment', 'participation', 'capacity building', 'good governance' and 'sustainable development'. The article presents the findings of a highly exceptional, but therefore very suitable case: a community-based forestry project in the Mafungautsi State Forest in Zimbabwe. This project used the same buzzwords throughout its two phases from 1994 to 1999 and from 1999 to 2003, but with remarkably different outcomes per phase. Only when the first donor left in 1999 due to Zimbabwe becoming an international pariah, was there space for another donor to reconceptualise the same buzzwords on different premises, leading to more positive outcomes. The paper concludes that, although rare in today's donor driven target culture, locally appropriate and critical operationalisation of buzzwords is possible even if, or perhaps when, it takes place under unthinkable circumstances.
\end{abstract}

\section{INTRODUCTION}

The notion of 'buzzwords' defined as policy catchwords or development concepts is nothing new (Cornwall and Brock, 2005). Conceptual frameworks in terms of specific wordings are of all times and form a fact of life in human societies where language is the principal mode of communication. But since all conceptual frameworks carry meaning and specific connotations, one has to be aware of their impact and effects. This article aims to do just that: to critically examine the effects of global development paradigms on the local level. Familiar 
examples of these 'buzzwords', are 'empowerment', 'participation', 'capacity building', 'good governance' and 'sustainable development'. From the literature, it is clear that policy concepts devised and operationalised in one part of the globe influence processes, institutions and developments in other parts of the world (Peet and Watts, 1993; Reinicke, 1998), with often the developed countries at the originating and developing countries at the receiving end. What is not clear, however, is how far this influence goes and how the effects of specific global conceptual frameworks on local processes and institutions can be characterised, even though they are often regarded as negative (Reinicke, 1998). Yet, despite being aware of possible negative impacts of buzzwords, Hicky and Mohan, in their study of participation, warn not to throw away the baby with the bathwater and so 'losing those elements of participation that retain the potential to catalyse and underpin genuine processes of transformation' (Hicky and Mohan, 2005: 257). They recommend that 'the conditions within which participation can be transformative, and the forms of politics that underpin such an approach, need to be closely delineated and analyzed' (Idem: 257). This then asks of us to not only examine how discourse influences behaviour, but also to analyse the complex interactions between discourse, institutions, leadership, and other sources of change. This is what we intend to do in this article by using the relationship between global development concepts and Community-Based Forest Management (CBFM) in Southern Africa.

The research reported here is based on a case study approach of a CBFM project in the Mafungautsi State Forest in Zimbabwe. In 1994, a joint management pilot project was set up by the Zimbabwe Forestry Commission, with assistance from a donor, the Canadian International Development Agency (CIDA), in order to generate lessons for the scaling up of such initiatives to other state forests in the country. Due to disappointing results and the overall decreasing donor interest as Zimbabwe became an international pariah, this project 
was prematurely terminated in 1999. It was soon thereafter resuscitated by a team of researchers from the Centre for International Forestry Research's (CIFOR) Adaptive Collaborative Management project (ACM), based in Zimbabwe. The ACM team used a different approach to forestry co-management, centred on enhancing social learning and collaboration among stakeholders. This provided space for stakeholders at the start of the project to come to grips with problems - and possible solutions - on their own terms. These two opposing outsets of the two phases of the project allows for an interesting comparison as it makes a division between what can be seen as more 'globalised' and more 'localised' conceptualisations of what are the problems at hand in Mafungautsi and what solutions can be developed to address them.

The article starts with a critical discussion of global governance buzzwords. Next, we provide some contextual background information on the development of forest policy in Zimbabwe and our case study area. This leads us to a description of the two phases of the Mafungautsi project, after which these are compared according to the buzzwords ownership, good governance, capacity building, participation and sustainable development. The article concludes by answering the question whether neoliberal global governance concepts are 'buzzing too far' into local level CBFM practices in Zimbabwe and outlines implications for development theory more general.

\section{GLOBAL GOVERNANCE BUZZWORDS}

When we talk about 'global governance buzzwords', three concepts, and their interrelations, need to be discussed: 'global', 'governance', and 'buzzwords'. We can be brief about the concept 'global'. Since it is an adjective giving the connotation of 'encompassing the whole world' to a noun, we can just accept it as such. Of course, one can say that the adjective 
'global' does not actually say how far the connotation goes, but the purpose of this article is to delve into this very question. With the next concept of (global) governance we find ourselves in more complex theoretical waters. Governance has been defined in so many ways that searching for an all-encompassing definition would be futile. Rather we outline what we think are important theoretical connotations to the concept, which are useful for the purpose of this article. We commence with the difference between government and governance.

According to Rosenau (2001: 1), both government and governance 'consist of rule systems, of steering mechanisms through which authority is exercised in order to enable the governed to preserve their coherence and move towards desired goals'. However, governance is a much broader concept than government, and distinguishes itself by its emphasis on 'any collectivity - private or public - that employs informal as well as formal steering mechanisms to make demands, frame goals, issue directives, pursue policies and generate compliance' (idem: 1, emphasis added). Government thus focuses more on formal systems of rule or steering mechanisms, usually at either local, regional, national or international levels. From the literature, it is evident that as a result of forces of globalisation a shift can be discerned from formal state-centred government to more informal governance, encompassing a wide range of actors, with differing levels of power in constantly changing alliances (Rosenau, 1997, 2001).

The fact that more and more actors are involved in constructing, influencing and implementing (environmental) policy renders power in the policy-process exceedingly diffuse and no longer a primacy of the state or bound to a specific locale (Biermann and Dingwerth, 2004). Increasingly, this has lead to the situation that 'the activities of external intervening agents can deeply influence the relationship of local communities with the natural resources' (Dietz, 1996: 44). Global actors more and more entitle themselves the right to intervene in and 
influence events at the local level, wherever this 'local' may be. In Southern Africa, this can be seen happening through the buying up of park lands by wealthy Western wildlife patrons, who then govern these parks on the basis of preservationist or protectionist principles (Büscher and Dietz, 2005) ${ }^{1}$. Naturally, these are sensitive developments in a region beset by conflicts over land and resources, where a continuously expanding number of actors are already grappling with 'hot' governance issues, such as decentralisation of authority, changes in tenure and incentive structures and the link between conservation and development (Boyd, 2001).

Another feature of modern (global) governance is that structures are opaque and simultaneously consist of fragmentative and integrative forces (Rosenau, 1997). With so many different actors on the scene, all with their own different agendas, backgrounds, visions and capabilities, contradictions are bound to be plentiful and one-dimensional frameworks hard to pursue. Still, this is not to say that structures do not exist at all. They are just not very tangible, often inconsistent and undoubtedly very complex. One identifiable form of structure lies in the construction of discursive configurations, together forming macro-ideological frameworks. Here is where we are getting to our last of the three concepts to be discussed: the global governance buzzwords.

Unlike governance, the term 'buzzword' has not been defined often. Here we describe it as a language unit that is produced, reproduced and transformed in a particular set of practices, which is widely used and accepted in many different contexts and through which meaning is transferred $^{2}$. Global governance buzzwords thus denote language units with strong ideological

\footnotetext{
${ }^{1}$ Preservationism or protectionism are generally regarded as the strictest forms of conservation whereby use of natural resources is not allowed and humans should refrain as much as possible from intervening is natural processes and landscapes.

${ }^{2}$ Adapted from Hajer's definition of policy discourse (Hajer, 1997: 44).
} 
and interpretative connotations, which are produced, reproduced and transformed in a particular set of practices and used and accepted in many different global rule systems and steering mechanism contexts. Together, these buzzwords make up a substantive part of the socalled global governance agenda that guides the formal development parameters insisted on by the majority of donors and international development agencies. We have already mentioned a few, but a more extensive, albeit not exhaustive list could include: sustainable development, empowerment, participation, capacity or institution building, (strengthening of) civil society, public-private partnerships and good governance. It is important to note here that buzzwords differ from discourses. While discourses are ensembles of particular words or phrases denoting a specific ideological meaning, buzzwords are individual language units that can be used without necessary reference to other words or phrases comprising a discourse. As such they might seem more disconnected of meaning, but we argue that this is not the case. All the above mentioned buzzwords stand, like discourses (Arts and van Tatehove, 2002), for ‘interpretative schemes’ by which meaning is portrayed.

It is fairly safe to state that the ideological interpretation and operationalisation of global governance concepts is predominantly derived from Western countries. After all, this is where 94 percent of all indexed scientific knowledge originates and where capacity to promote this knowledge is available (Karlsson, 2002). This incredible domination of discursive power is also shown by the fact that buzzwords often do not even get translated anymore when introduced into a non-English language (Ergun and Cali, 2002). While this statement may seem trivial, the consequences may be quite far-reaching. Buzzwords, like discourses, operationalised in one place and context may not necessarily be suitable in any other place or context. From the literature, we have distilled three ways how this could work out: 1) the ideological operationalisation of the buzzword; 2) contradicting conceptions within the 
buzzword and 3) loss of meaning through the usage of buzzwords for political legitimation.

The first, widely accepted, argument why one has to be careful using global governance buzzwords on a global scale is because the ideological operationalisation of the concept may not suit just any place or context, with its own specific culture, history and (political-) ideological settings. Many writers specifically refer to the neoliberal discourse, with its emphasis on economic and financial logic, privatisation and liberalisation, as the basis on which influential global players, such as the IMF, World Bank, the UN, the USA and the EU, devise and operationalise the global governance agenda (Peet and Watts, 1993; Adejumobi, 2000; Tsheola, 2002; Rosenau, 2003). Rosenau, for instance, states that 'sustainable development 'now (...) connotes (...) with the emphasis on sustaining economies rather than nature, a semantic shift that has enabled a vast array of diverse actors to crowd under the umbrella of sustainability and to press their goals in the context of what they regard as unquestionable sets of values' (2003: 16). Global governance buzzwords in this sense thus directly denote neoliberal values, which are portrayed as being unquestionable and universally applicable. That this assertion itself is very questionable or at least heavily contested can for example be demonstrated by the overwhelming critique on the former structural adjustment policies of the IMF and World Bank (Schatz, 1994).

The second argument why global governance buzzwords should be treated with care is that they are often contradictory in nature, or to other buzzwords. Weiss for example explains that the World Banks position on good governance is 'preoccupied with public sector management, the reduction of transactions costs and contract enforcement' and as such contrasts with governance approaches that support local participation and empowerment (2000: 804). Clearly, the latter two buzzwords are crucial within the theory and practice of 
CBFM. Jan Pronk, former Dutch minister for Development Cooperation, recently gave another example (Pronk, 2004). Building on his vast international experience, Pronk also argued that buzzwords like good governance are operationalised on the basis of western notions of development or progress, which contain contradictory elements that could be harmful or even outright negative for the development of the African continent. According to Pronk, good governance is latently used in a (neoliberal) context of stability. Development, however, implies change, leading to a different allocation of resources and capital, which by definition involves a restructuring of the status quo. In Africa in particular, changes in the status quo often involve conflict or even violence, and thus call for policies aimed at conflict resolution. In contrast, the static conception of good governance in a context of stability focuses more on conflict control and as such does neither contribute to the dynamic process of development nor to ownership over Africa's development by Africans themselves.

These two arguments feed into the last argument put forward here that buzzwords are often included into all sorts of management, policy or governance documents for the single purpose of political legitimation (Mosse, 2005). Many actors depending on donor support feel they have to speak the donor language and subsequently feel obliged to incorporate ownership, sustainable development, participation and other 'mobilising metaphors' (Idem) into their texts. While we have already argued that we should be cautious for reasons of predetermined or contradictory content, the usage of buzzwords might also be hazardous for the reason of lack of content altogether. Clearly, when using a (foreign) word to explain or describe an issue, one not only tags along ('foreign') meaning, but also looses the option of developing a concept or word that states what is actually meant or wanted in the domestic language (Ergun and Cali, 2002; Eriksen, 2005). Hence, loss of meaning occurs, while it is essential in local development that local actors can describe or explain development in such a way that is has 
local meaning. After all, this is (or should be) what the popular buzzword of ownership is based on.

Concluding, it has to be noted that the issue of global governance buzzwords is not something that has arisen in a historical vacuum. On the contrary; contemporary global governance buzzwords are arguably the latest episode in a long historical context of Western domination over Africa (Cooper, 2001). Hence, one needs be very sensitive to, and even critical of the discursive side of development processes. We now turn to a case of local 'sustainable development' through Community Based Forest Management in Zimbabwe in order to analyse the effects of global governance concepts in the context of the above discussion.

\section{THE DEVELOPMENT OF FORESTRY POLICIES IN ZIMBABWE}

In order to sketch the context in which the projects in the Mafungautsi forest took place, this section will briefly describe the development of forestry policies in Zimbabwe. The forestry policy-making process in Zimbabwe (then Rhodesia) has been highly influenced by policies used by the British Empire (now the Commonwealth) Forestry Association. According to Matose, the 'Association forms the knowledge centre through which peripheral places like the Rhodesia Forestry Commission had access to forest conservation arguments which influenced policy framing in order to command and control forests in their own boundaries and territories' (Matose, 2002: 53). Because of limited staff, the officials from the Rhodesia Forestry Commission depended on information and knowledge from institutions such as the Oxford Forestry Commission in order to formulate forestry policies, and it is only around the 1990s that results from local indigenous forest research began to filter into the policy making process (Pearce and Gumbo, 1993). 
The biodiversity and watershed conservation debates that dominated earlier in the century centred around scientific arguments on the relationships between climate, deforestation and hydrology. According to Matose (2001: 70): 'hydrology and climate were highly topical within the empire debates up to the 1940s, but their significance in policy framing has diminished since then'. However, ideas on the role of forests in watershed conservation have continued to persist in forest policy formulation, also in post-colonial Zimbabwe. Debates during the commonwealth forestry conferences were centred on the conviction that indigenous forests in most countries lie on Kalahari sands that are fragile and susceptible to erosion and therefore need protection. This conviction also influenced forestry policy formulation in Rhodesia, resulting in the demarcation of most forests as state forests to be managed in a top-down fashion by the Forestry Department. Moreover, because some of the forests in the commonwealth countries were rich in commercial timber species, there were debates earlier in the century on how best production from these forests could be maintained and sustained in the commonwealth countries. According to Matose, 'the sustained yield agenda was set in motion with the resolution on the forest technique at the Commonwealth Forestry conference of 1923 that spelt out the need for sound management. This entailed working plans for regulating yield, spelt-out objectives, the calculation and regulation of the yield to be obtained from each forest, and a spread of age classes of trees for future harvest' (2001: 61). At this conference, all governments were urged to come up with management plans that would ensure sustained yields of forest products.

As can be seen from the above discussion, the policies that were crafted in the early years of the $20^{\text {th }}$ century were protectionist in nature. However, because of the other international debates on failure of the protectionist way of managing natural resources in the late 1980s (Adams and Hulme, 2001), ideas on people centred approaches began to filter in the policy 
making process in Zimbabwe ${ }^{3}$. The Forestry Act began to allow experiments with such approaches, and this resulted in the initiation of the pilot resource-sharing project in Mafungautsi State Forest, where the Forestry Commission (FC) decided to bring communities on board to help in the management of the state forest. In the resource sharing project, communities were now allowed to legally harvest products such as broom and thatch grasses, fruits and mushrooms, only to mention a few, but they were not allowed to harvest the high value commercial timber species. To some extend, the project went beyond the provisions of the Forestry Act, as this was illegal before the project started.

\section{THE MAFUNGAUTSI FOREST, ZIMBABWE}

Mafungautsi State Forest is located in Gokwe South District in Midlands Province, Zimbabwe (See figure 1). The forest has a total area of 82,100 hectares, which makes up $17 \%$ of the district. Communal areas in the district cover a total of $73 \%$, while the remaining $10 \%$ is covered by national parks and small-scale commercial farms.

\section{[Insert figure 1 approx here]}

Vegetation in Mafungautsi is predominantly Miombo woodland and the dominant tree species are Brachystaegia and Julbernadia (Vermeulen, 2000). The dominant soils in Mafungautsi forest are Kalahari sands and only a few patches can be found with sodic and heavy clay soils. The forest is a catchment area for four major rivers in Zimbabwe, namely; Sengwa, Mbumbusi, Ngondoma and Lutope. Conservation of the watershed was one of the main reasons why it was protected as a state forest in 1954. Mafungautsi forest is a source of

\footnotetext{
${ }^{3}$ One must note here that after two decennia wherein community based approaches to conservation were the dominant paradigm, the end of the 1990's saw more and more fundamental critique to these approaches. Some have even argued that the debate it now taking a U-turn 'back to the barriers'; back to protectionist thinking. See Brechin et al, 2002; Hutton et al, 2005)
} 
several resources including pastures for grazing animals, thatching grass, broom grass, medicinal plants, honey, mushrooms, firewood, construction timber, game meat, Mopane worms ${ }^{4}$ indigenous fruits and herbs. The majority of stakeholders around Mafungautsi belong to two ethnic groups: Ndebele and Shona. A minority belong to the following ethnic groups: Tonga, Kalanga, Chewa and Shangwe.

The initiation of a resource-sharing project in 1994 brought some changes in forest management in Mafungautsi forest. In line with the global governance climate that was then really beginning to shape up, the main aim of the project was to enable surrounding communities to take an active role in the management of the forest resources, leading to participation and ownership. Fifteen Resource Management Committees (RMCs) were set up in various communities surrounding the forest and their main role was to monitor and control harvesting of the resources, to which communities were now allowed access. The same aim of involving communities into joint management was central in the second phase of the project that started in 1999, but departed from totally different premises through the Adaptive Collaborative Management (ACM) approach. The next two sections describe these two phases. After that, they will be analysed according to the four global development principles that seem most appropriate and close to the ultimate goals set out by these projects: participation, ownership, good governance and capacity building. As the overall goal of the project has been termed sustainable development, we will also take this concept into account ${ }^{5}$.

\section{THE RESOURCE SHARING PROJECT: 1994-1999}

This section presents a descriptive analysis of what transpired after the launch of the resource-

\footnotetext{
${ }^{4}$ Mopane worms (imbresia belina) are edible and used as a relish when dried.
} 
sharing project, which was mainly driven by donors, the most important of which was CIDA ${ }^{6}$. The main activity after the launch of the resource-sharing project was the creation of Resource Management Committees (RMCs) in the communities surrounding the forest by the FC. RMCs were supposed to act as a link between the FC and the communities. Their main tasks involved administering permits for resource users to harvest the minor forest products, monitoring the harvesting process, opening and keeping a community bank account where the moneys raised through the permit system where to be kept and finally advising the community on how the funds could be spent. All of this had to ensure a sense of ownership with the communities which, so said the theory behind the project, was to lead to better community participation in sustainable forest management.

The creation of the RMCs was the Forestry Commission's way of operationalising the concepts of ownership and participation. However, the communities around Mafungautsi were never consulted and it was not clear how the new committee would fit in the already complex institutional landscape (Mapedza and Mandondo, 2002). Most communities were not clear on what the role of the RMCs was and hence saw them as an extended arm of the FC. This later brought in a lot of tensions. The RMCs themselves were accountable only to the FC and they did not pay due respect to the already existing traditional leadership structures. This in turn resulted in conflicts arising between traditional authorities and RMC members. For instance, when RMCs organised meetings, some village heads and their community members never came. Also, the way the RMCs were formed was mostly top-down. In some cases, the FC officer just send word that seven people from a community should come and see her. The people who came were then elected as the RMC committee. By now, it is generally accepted

\footnotetext{
${ }^{5}$ In what follows, one can undoubtedly distinguish more common buzzwords, such as 'community' and 'biodiversity', which we agree with an anonymous reviewer also deserve scrutiny but we do not do so here due to space constraints.

${ }^{6}$ Canadian International Development Agency
} 
that the FC was not very genuine in its attempt to involve local people in the management of the forest, but merely wanted to recruit cheap labour from a number of community people to increase their forest guards.

The RMCs were also told by the FC to open a bank account in order to deposit the money raised through the issuing of permits to resource harvesters in the forest. Although it was said to belong to the communities, a FC officer was a signatory to the account. The communities could not withdraw money without approval from the FC, showing the extended paternalistic spirit by the FC. Both the setting up of the RMCs and the bank account were, according to FC rhetoric, meant to empower the local people to manage and really make them the owners of the resources but in practice, this was never the case. The FC remained reluctant to hand-over power to the locals to make their own decisions about what basically were to be their own money and resources.

Later in the project, these various conflicts were to be solved through the introduction of good governance. However, the several conflicts that continued to plague the project were never seriously addressed (Mutimukuru, 2004), whereby it seems that the FC judged the situation on the ground to be more stable than it actually was. No mechanisms were set up to really resolve the conflicts after the introduction of the resource sharing project. The good governance 'mode' of the FC was, similar to Pronk's (2004) example, directed too much at conflict control, while a change in the institutional landscape, such as that of the introduction of the RMCs which aggravated the already existing conflicts tensions, rather called for an investment in longer-term conflict resolution, instead of short-term conflict control. As a result, the chaotic relationship that existed between the two major stakeholders never improved during the resource-sharing project, and the condition of the forest continued to 
deteriorate as communities continued to access the forest resources outside the project.

In the end, it took a third party to break the impasse. In 1999, when CIDA had left and the Centre for International Forestry Research (CIFOR's) Adaptive Collaborative Research (ACM) was initiated in the resource sharing project, the ACM researchers could not go to the field in a FC vehicle as any association with the FC would result in non-cooperation from the communities. The researchers had to separately meet with the two stakeholders at first to identify the type of conflicts and problems that existed. It took about a year for the relations among these stakeholders to improve. Nowadays, the relations have become better, after the conflict solution mechanisms employed by the team, and the communities do not mind anymore even if the researchers go to the field in a $\mathrm{FC}$ vehicle.

\section{THE ADAPTIVE COLLABORATIVE MANAGEMENT RESEARCH PROJECT}

$1999-2003$

The lack of progress in the resource-sharing project was the entry point for introducing CIFOR's ACM research project. The ACM approach ${ }^{7}$ was introduced to add value to the joint forest management scheme that was in place around Mafungautsi Forest between the Forestry Commission (on behalf of the State) and local communities. The scheme, as seen from the above, had not improved collaboration between the State and local communities, as had been intended at the start in 1994. Thus the focus of this CIFOR initiative was on developing approaches that would enhance learning and improvement on existing management systems.

The main thrust of this research was to facilitate reform of management practices, institutional

\footnotetext{
${ }^{7} \mathrm{ACM}$ is a value-adding approach whereby individuals or groups who use or manage a forest, agree through a process of participatory action research to act together and draw up plans for their forests. These plans are then implemented with the recognition that they may not fulfill their intended objectives. In this process, it is important for people to learn collaboratively from the implementation, as changes in the plans are negotiated.
} 
arrangements and policies in order to promote forest management systems that would lead to both human and ecological benefits. The project aimed at facilitating a shift away from blanket prescriptions of solving problems and moving towards locally based management that has freedom to adapt to rapidly changing circumstances in a manner that is in accordance with sustainable forest management and meeting the needs of local communities. The specific purpose was to facilitate widespread use of self-improving and equitable forest resource management systems that build on local capacity, 'vertical' and 'horizontal' stakeholder interactions, and responds positively to external pressures.

To kick off the research project, the ACM team conducted a baseline survey. One of the major finding of this baseline was that local people were passive and felt disempowered to actively participate in the management of the state forest. To break this passiveness, the research team facilitated local communities to go through a Training for Transformation ( $\mathrm{T}$ for T) workshop, that was based on six principles developed by Paulo Freire: 1) no education is neutral as it can domesticate or liberate you, 2) education should be relevant, 3) education should promote dialogue, 4) education should encourage a process of reflection and learning, 5) education should promote radical transformation and 6) people should be critical when trying to solve problems and searching for solutions.

After the $\mathrm{T}$ for $\mathrm{T}$ workshop, communities were more confident and started to participate in the resource-sharing project differently than they had done before. Women and marginalized groups who used to be left out in management began to take an active role in issues concerning the forest resources. Currently, communities have even taken over the running of the project as the FC takes a back seat. Moreover, community members have not only monitored their activities in the forest, but have begun to actively monitor the functioning of 
the RMCs and demanding accountability. In cases where the RMCs were not performing according to the requirements of the community members, such RMCs have been removed from power and new members have been elected. In one RMC, Batanai, subcommittees that have been set up by the FC initiative in an effort to lesson the work done by RMC members have been dissolved as they failed to meet the community's expectations.

These developments were, besides the $\mathrm{T}$ for $\mathrm{T}$ workshops, also sparked by efforts to 'build capacity', something that had also been tried in the previous project, but had yielded little results. New efforts in the ACM project to build capacity of the communities around Mafungautsi included 'look and learn' tours, feedback and training workshops and several discussion and learning platforms that were created to enhance sharing of experiences and learning among stakeholders. An example of a look and learn tour is presented in box 1 below.

\section{[Insert box 1 approx here]}

In the above case of the 'look and learn tour' to Nyagadza, it is clear that capacity building was not only for local communities but also for the FC officers. Both stakeholders learnt about systems for sustainable harvesting and utilizing timber resources. After the tour, steps were taken by the FC officers to try and incorporate timber harvesting in the resource-sharing project. Other efforts to build capacity for the stakeholders involved training workshops - the FC officers and community representatives also went through training on participatory approaches and their implications. The FC officers also attended training workshops on the ACM approach and this helped them to gain a clearer conceptualization of participatory approaches in their extension work. Finally, in the various platforms that were organized, 
local potential was unlocked through sharing of experiences, learning among stakeholders at various levels, and this helped to 'build capacity' as well.

The combined efforts in capacity building of both the FC and the community members resulted in more meaningful participation in the management of the forest than had previously been thought possible. Some empirical examples hereof can be found in the two boxes below.

\section{[Insert box 2 \& 3 approx here]}

These cases show that local people have been taking a lead in actively participating in the management of their resource. By coming up with new permit systems, stakeholders in Batanai show a keen interest in monitoring their firewood resource, and that they also want to ensure that their resources are sustained. This also applies to the Gababe case, where they also wanted to monitor their resource in addition to solving their equity problems. In both cases, local solutions were sought by local stakeholders in trying to deal with the problems they face, and unlike previously where participation by locals was by tokenism, here we see what is actually meant by participation emerging.

After the introduction of the ACM research project, considerable time was spent in explaining what the project was all about and this greatly helped in creating ownership of the project by the local people. In the Chemwiro Masawi case (see box 5 below), the local people were anxious to know the role of the RMC according to the constitution. This was the first time that the constitution was explained to them, and when they now had knowledge about it, they were keen to start monitoring the performance of RMC members. Furthermore, communities became more proactive in assuring the representativeness of the new RMCs. The following 
case in box four illustrates this point.

\section{[Insert box 4 approx here]}

The above case clearly shows that RMCs are no longer accountable to the FC only but also to the communities they represent, which is normally regarded as one element of good governance. This came about because the communities have taken an active role in monitoring the performance of their RMCs and those that do not perform well were dissolved. Another example of a case where communities demanded downward accountability by their RMCs is given below:

\section{[Insert box 5 approx here]}

Facilitation of the various processes by the ACM team in Zimbabwe ended in 2003. To ensure that learning and collaboration processes would continue even after the ACM researchers withdrew, a strategy was developed to equip the local FC officers and community partners with facilitation skills. The FC officers were also trained in the ACM approach. This proved instrumental as community partners and FC officers remained actively involved in facilitating the learning processes. It is also important to highlight that the researchers did not pull out drastically, but did so gradually. At first, the researchers offered considerable back-up support to the two main facilitators, the community partners and the FC officers. However, this support decreased as time went on and stakeholders became more confident in organising and facilitating the learning processes. The researchers have now become mere observers as learning processes continue to unfold with the facilitation of the community partners and the FC officers. 


\section{ANALYSIS: BEYOND BUZZWORDS?}

The two phases of the Mafungautsi Resource Sharing Project show clear differences in terms of success. The resource sharing project generally failed to meet any of the goals behind participation, ownership, good governance, capacity building and thus sustainable forest management. To the contrary, the ACM project did manage to meet many of the goals set out by the resource sharing project, while putting emphasis on the same buzzwords, but taking a whole different approach altogether. Here we will shortly analyse the key differences of the two projects in terms of the five buzzwords concerned.

Before the ACM team intervention in 1999, although the policy was flexible to allow for the resource sharing project to take place as an experiment, events in practice did not portray this. The FC did not trust that communities could also effectively participate in the project, but since the donors were funding this project, buzzwords such as capacity building, participation and community empowerment dominated most discussions about the resource sharing project even though there was incomplete understanding of what exactly these words meant. For example, capacity building of communities, in order for them to effectively participate in the project, had been high on the agenda, but never materialised. Government and FC officials' perceptions on what needed to be done in order to 'build capacity', differed greatly from what is generally understood by the term: to increase the competence (intellectual, financial, economic, etc.) of the communities in order for them to become better equipped partners in the project. The FC continued to operate as they used to do before the project, with policing being their main approach for 'good governance' and management, leading to an increase in the arrest of community members and subsequent worsening of the relations. Hence, the introduction of capacity building of communities did not have any effect in the project as the 
actors that had to do this capacity building saw the concept as void of any meaning, other than its use of political legitimation. Capacity building thus works both ways and it would have been better if the FC officials had had training in order to change their own perceptions.

After the introduction of the resource-sharing project, communities were required to actively participate in the management of the forest and yet they were ill equipped to do so. Because of their past history, communities had the belief that the government forest officials knew everything and they knew nothing. Even during the initial stages of the ACM research project, communities refused to answer any questions and told the researchers that they did not know anything. Even though the two major stakeholders, the FC and communities were supposed to collaborate and manage the forest resource, the FC continued to dominate while communities continued with their 'business as usual.' Participation by communities was therefore by tokenism and upon this realisation - further reinforced by Zimbabwe becoming an international pariah -, the donor, CIDA, instead of trying to see how things could be changed, decided to pull out of the project and leave it in limbo.

After the introduction of the ACM approach, there has been an evolution of a new partnership between the two major stakeholders, the FC and communities that have resulted in the better management strategies and the improvement of human lives. After the training in the ACM approach, the FC officers had moved from being teachers to being learners, and increasingly appreciated local people's knowledge. This resulted in the two main partners learning from each other and improvements in the management of the resource compared to the initial stage where the FC claimed to know everything and regarded communities as lacking knowledge. In recent developments, the two partners have also started initiating joint learning processes and they have participated in look and learn trips whereby both community members and 
local people visited a carpentry project in Chipinge in the Manicaland province of Zimbabwe.

In the new project, deliberate effort was put in building the capacity of the local stakeholders. After realising that local people had inertia, the ACM team organised the $\mathrm{T}$ for $\mathrm{T}$ workshop, which helped to boost the local stakeholders' confidence and level the playing field. In addition to the $\mathrm{T}$ for $\mathrm{T}$ workshop, researchers also used other methods to try and break passiveness by communities. For instance, through facilitation by researchers, previously marginalized groups were deliberately given platforms to express themselves, and take lead in issues that concerned them. This helped a lot in raising the confidence of women. Invitations for most of the workshops organized by the researchers, were deliberately extended to mostly women, and other marginalized groups, and this also boosted their participation in the processes, and also enhanced their confidence and self-belief.

After the ACM research project, community participation in resource management and decision-making processes was enhanced and by making decisions the local stakeholders also demanded more genuine ownership of the project. As forest product user groups implemented their action plans, their collaboration with the RMC, FC and other district level stakeholders improved. Forest users now had a means of engaging with both the RMC and Forestry Commission on their terms, and this improved their collaboration. As a result of this improved collaboration, communities' perceptions towards the Forestry Commission became more positive, they began to see the FC as more of an ally than a hindrance to resource access. All in all, the latest developments in Mafungautsi have instigated a more regulated and balanced approach to meeting the needs of the communities, while not over harvesting the forest resources. Perhaps it is too soon to call this 'sustainable forestry development', but steps in the right direction have surely been made. 


\section{CONCLUDING THOUGHTS}

As is clear from the foregoing, it is not so much the specific wording that is used that made the difference between the two phases of the project. Rather, the difference lies in who operationalises a buzzword like participation or ownership and how. Of course, this in itself is nothing new, but what the Mafungautsi case clearly illustrates is that discursive pressure involved in a donor instigated project makes it much more susceptible to problems of unfitting ideological operationalisation, contradictions and lack of meaning because of political legitimation. However, the case also shows that this conclusion is not unavoidable. When ACM researchers from CIFOR came with a different approach that focused on enhancing social learning and collaboration among stakeholders, local community members got an opportunity to come to grips with their problems - and possible solutions - on their own terms.

Donor money almost always comes with conditions. In the Mafungautsi case, the FC had to adopt the resource sharing approach which was directly influenced by the emerging global governance agenda where people had to move from top-down approaches - to people oriented approaches through buzzwords such as 'participation' and 'empowerment' of local people. Coming back to our three ways of how buzzwords often work out in reality, as noted in the theoretical section, it can be concluded that for the case of Mafungautsi State Forest, the buzzwords were not clearly defined at that level and stayed just buzzwords with no local meaning and were mainly used by the Forestry Commission to legitimate donor funds.

Moreover, it can be concluded that the various global governance buzzwords work out differently in different situations. The Mafungautsi case showed for example that the term 
capacity building was mostly used for purposes of political legitimation, while the adhering to good governance in the project showed internal contradictions in the way conflicts ought to be managed. Above all, the buzzwords lacked meaning at the local level and subsequently made implementation complicated. The resource-sharing project was immediately implemented by the FC without much consideration of other factors that were crucial if the project was to be successful in enhancing real effective participation of local people. Such factors could include: levelling the playing field; besides only building capacity for local communities, also building capacity for government workers on people oriented approaches; and training in order to change perceptions of capabilities of local people and executing real good governance through conflict resolution mechanisms. Things that we saw happening in the ACM project.

All of this leads to the bigger debate on the effectiveness and legitimacy of development cooperation through donors and international institutions. To find a case in Zimbabwe, now internationally under much pressure and stigmatised as a negative spiral downwards, where certain things are actually improving after a change of donors ${ }^{8}$, at least points to the conclusion that buzzwords can indeed 'retain the potential to catalyse and underpin genuine processes of transformation' (Hicky and Mohan, 2005: 257). This is an important conclusion in a time whereby many donors and development practitioners merely seem to put emphasis on correct project processes whereby all the 'right elements (buzzwords) can be found, rather than on how these elements are implemented in such a way that they take into account local realities and power dynamics. The above case therefore again prove that not only a critical rethinking of the development process is necessary. Arguably even more important, it confirms that donors and development practitioners should accept critical thinking by local 
recipients of aid vis-à-vis global governance buzzwords and stimulate the flexible and local interpretation thereof.

\section{REFERENCES}

ADAMS, W \& HULME D, 2001. Conservation and community. Changing narratives, policies \& practices in African conservation. In Hulme, D \& Murphree, M (Eds), African wildlife and livelihoods. The promise and performance of community conservation. Oxford: James Currey.

ADEJUMOBI, S, 2000. Africa and the challenges of democracy and good governance in the $21^{\text {st }}$ Century. In Proceedings of the Second DPMF Annual Conference on Democracy, Civil Society and Governance in Africa, Addis Ababa, Ethiopia (7-10 December 1998). Addis Ababa: United Nations Economic Commission for Africa.

BIERMANN, F \& DINGWERTH, K, 2004. Global environmental change and the nation state. Global Environmental Politics, 4(1): 1-22.

BOYD, C with contributions from JONES, BTB \& ANSTEY, S \& SHACKLETON, S \& FABRICIUS, C, 2001. Sustainable livelihoods in Southern Africa: institutions, governance and policy processes, SLSA Working Paper 5, Wild resources Theme Paper. Sussex: IDS, University of Sussex.

BRECHIN, SR \& WILSHUSES, PR \& FORTWANGLER, CL \& WEST, PC, 2002. Beyond the Square Wheel: Toward a More Comprehensive Understanding of Biodiversity Conservation as Social and Political Process. Society and Natural Resources, 15: 41-64.

BŪSCHER, BE \& DIETZ, T, 2005. Conjunctions of governance: the state and the conservation-development nexus in Southern Africa. Journal of Transdisciplinary Environmental Studies, 4(2): 1-15. Online: http://www.journal-tes.dk/

\footnotetext{
${ }^{8}$ Interestingly, after realising the positive developments in the resource sharing project after the introduction of the CIFOR ACM research, CIDA came back to fund the upscaling of the ACM approach to two neighbouring
} 
COOPER, F, 2001. What is the concept of globalization good for? An African historian's perspective. African Affairs 100: 189-213.

CORNWALL, A \& BROCK, K, 2005. What do buzzwords do for development policy? A critical look at 'participation', 'empowerment', and 'poverty reduction'. Third World Quarterly, 26(7): 1043-1060.

DIETZ, T, 1996. Entitlements to natural resources. Contours of political environmental geography. Inaugural speech University of Amsterdam. Utrecht: International Books.

ERGUN, A \& CALI, C, 2002. Global governance and domestic politics: fragmented visions. Paper presented at the CPOGG workshop, Amerang (1-3 November).

ERIKSEN, TH, 2005. McDonaldisation or diversity? Notes on the use of English as a foreign language. Keynote speech to the conference 'Bi- and multilingual universities: Challenges and future prospects', University of Helsinki (1-3 September). Online: http://folk.uio.no/geirthe/EFL.html.

FERGUSON, J, 1994. The anti-politics machine. 'development,' depoliticization, and bureaucratic power in Lesotho. Minneapolis: University of Minnesota Press.

FRIEDMAN, TL, 2000. The Lexus and the Olive Tree. New York: Anchor Books.

HAJER, MA, 1997. The Politics of environmental discourse: ecological modernization and the policy process. Oxford: Oxford University Press.

HICKY, S \& MOHAN, G, 2005. Relocating participation within a radical politics of development', Development and Change 36(2): 237-262.

HUTTON, J \& ADAMS, WM \& MUROMBEDZI JC, 2005. Back to the barriers? Changing narratives in biodiversity conservation, Forum for Development Studies 2: 341-370.

KARLSSON, S, 2002. The North-South knowledge divide: Consequences for global environmental governance. In Esty, DC and Ivanova, MH (Eds,), Global environmental governance. Options and opportunities. New Haven: Yale School of Forestry \& communal areas, Jahana and Simchembu. 
Environmental Studies.

MAPEDZA, E \& MANDONDO, A, 2002. Co-management in the Mafungautsi State Forest area of Zimbabwe - What stake for local communities? Working Paper no. 5, Working Paper Series on Environmental Governance in Africa. Washington D.C: World Resources Institute. MATOSE, F, 2001. Local people and reserved forests in Zimbabwe: What prospects for comanagement? Unpublished $\mathrm{PhD}$ dissertation, University of Sussex.

MOSSE, D, 2005. Cultivating Development. An Ethnography of Aid Policy and Practice. London: Pluto Press.

MUTIMUKURU, T, 2004. Managing conflicts for sustainable forest management. A Case of Mafungautsi State Forest, Zimbabwe. Paper presented at the International Association for the Study of Common Property biannual conference, Oaxaca, Mexico (9-13 August).

MUTIMUKURU, T \& KOZANAYI, W \& NYIRENDA, R, 2006. Catalysing collaborative monitoring processes in joint forest management situations. The Mafungautsi Forest case, Zimbabwe. Journal of Society and Natural Resources, 9(3): 209 - 224.

PEARCE, GD \& GUMBO, D, 1993. Natural regeneration of indigenous trees: The key to their successful management. In Pearce, GD \& Gumbo, DJ (Eds), The ecology and management of indigenous forests in Southern Africa. Harare: Proceedings of international Symposium of the Forestry Commission and SAREC, Victoria Falls, Zimbabwe (27-29 July 1992).

PEET, R \& WATSS, M, 1993. Introduction: Development theory and environment in an age of market triumphalism. Economic Geography 69(3): Environment and Development, 1: 227 253.

PRONK, JP, 2004. Public lecture on good governance at the 'Africa Day' of the Evert Vermeer Stichting, Utrecht, The Netherlands (3 April 2004).

SCHATZ, SP, 1994. Structural adjustment in africa: A failing grade so far. Journal of Modern 
African Studies 32(4): 679-692.

REINICKE, WH, 1998. Global public policy. Governing without government? Washington DC: Brookings Institution Press.

ROSENAU, JN, 1997. Along the domestic-foreign frontier. Exploring governance in a turbulent world. Cambridge: Cambridge University Press.

ROSENAU, JN, 2001. Strong demand, huge supply: Governance in an emergent epoch. Paper presented at the international conference Multi-Level Governance: Interdisciplinary Perspectives, Sheffield, United Kingdom (28-30 June).

ROSENAU, JN, 2003. Bleak prospects for sustainability, Internationale Politik und Geselschaft 3: 11-29.

TSHEOLA, J, 2002. South Africa's form of globalisation: a continental posture paradox for insertion and dependence. Political Geography 21: 789-811.

VERMEULEN, SJ, 2000. Setting the context of the Mafungautsi Forest (Zimbabwe) project in a criteria and indicators Framework. Harare: ACM programme, CIFOR.

WEISS, TG, 2000. Governance, good governance and global governance: Conceptual and actual challenges. Third World Quarterly, 21(5): 795-814. 